\title{
The development of PQ4R-based LKPD to improve the fourth grade students' thematic
}

\section{learning outcome}

\author{
Anadya Tri Sabrini ${ }^{1 *}$ \\ Dwi Yulianti² \\ Dina Maulina ${ }^{3}$ \\ ${ }^{1,2,3}$ Postgraduate Program, University of Lampung, Bandar Lampung, Indonesia
}

\begin{abstract}
This research aims to analyze the need of LKPD development in accordance with the learning model used. This research was a descriptive quantitative research. The research subjects were teachers and students of grade IV at State Elementary School (SDN) 2 Kampung Baru. The data were collected using interviews, observation, and questionnaire, which were analyzed through a descriptive analysis. The results show that the competence standard, basic competence, and competence achievement indicators were in line with the Curriculum 2013. The students' learning outcomes were categorized into low category. The PQ4R is one of models that can be applied for improving students' learning outcomes. The teachers need a suitable LKPD for the learning model, suitable with students' characteristics. This research can be further developed referring to the PQ4R learning model for improving learning achievement.
\end{abstract}

\author{
KEYWORDS \\ LKPD, PQ4R, Learning outcome
}

Received: 2 August 2021

Accepted: 14 August 2021

Published: 20 August 2021

\section{Introduction}

Education is a process to affect students to be able to adapt as best as possible to their environment. Basically, the growth and development of students depends on two elements that influence each other, namely the talents owned by students from birth and the environment that influences them to grow and develop. School as a formal educational institution, systematically, it plans various environments, such as an educational environment that provides various opportunities for students to share learning activities. With these various learning opportunities, the growth and development of students is directed and encouraged to achieve the desired goals. The environment is arranged and arranged in a curriculum, which in turn is implemented in the form of a learning process. Learning is a system made up of numerous components that are all linked together. Objectives, materials, procedures, and assessment are some of these components. When selecting and determining which learning models will be used in learning activities, the instructor must examine the four learning components.

The curriculum used in the learning process has developed from time to time. These developments occur because of the demands of advances in science and technology as well as the needs of life. The development of each curriculum is an improvement from the previous curriculum. The basic concept of the 2013 curriculum is in an effort to simplify and its thematic integrative. Integrated thematic learning with a scientific (scientific) approach. In thematic learning also uses assessment (authentic assessment) which assesses the readiness of students, processes, and learning outcomes as a whole. Students are supposed to have far better attitudes, skills, and knowledge capabilities as a result of this strategy, as well as be more creative, innovative, and productive.

Previous research on the development of printed textbooks previously indicated that the literacy skills of Indonesian in 3rd grade students of elementary school in reading and writing had been successfully carried out and it had a significant impact on student learning outcomes. And several studies that combine the development of LKPD use the PQ4R method to implement LKPD in the classroom. The research gap can be seen in the explanation of the stages of comic production that is not clearly presented and comics as learning media are presented at the Reading learning stage only in the PQ4R method. Thus, this current study examines the development of LKPD by using all stages of learning in the PQ4R method. Considering that the learning objectives are in accordance with the Law of the Republic of Indonesia No. 20 of 2003 concerning the National Education System that "Education is a conscious and planned effort to create an atmosphere and learning process so that students actively develop their potential to have religious spiritual strength, self-control, personality, intelligence, noble character, and skills needed by himself, 
society, nation and state", Narrative stories of educational comics must contain religious spiritual values in them. Another reason for choosing comics media is because this media is very interesting in students' lives and is widely available in reading shops and it is a reality that some students can recognize and remember the characters and comics they see (Rohani, 1997). They are accustomed to calculating basic calculations and procedural questions and lack contextual problem solving that requires argumentation and creativity in solving them. According to a survey by The Pew Forum on Religion and Public Life, Islam is the majority religion in Indonesia, reaching $87.2 \%$ of the total population, even the largest in the world. Islam is the true religion that establishes a number of norms or principles of life. The principles of Islam become a role model for the community as a result of the acculturation process of local culture and Islam, making Islam not only a religion but also Indonesian culture.

Dealing with the problems described above, this study examines how to implement the development structure of thematic LKPD-integrative PQ4R. The results of this study are expected to support the development of thematic-integrative LKPD and it can be learning media.

\section{Research method}

This study used descriptive qualitative research. The population in this study was the fourth grade students at elementary school toward the teacher working group of cluster 2 which located in the district of Lauha Ratu and it consisted of 150 students. Whereas, the sample used was through a random sampling technique or using a random sample of fourth grade of elementary school students in the working group of cluster 2, Labuhan Ratu district, and it consisted of 35 students. The objective sampling strategy was chosen due to it is easy to collect information from participants that is easily accessible by researchers. The data collection technique used was interviews and questionnaires. The analysis technique used was qualitative data analysis techniques, namely analysis of data sourced from the data collected from the interview process and the administering questionnaires with people related to what will be studied.

\section{Results and discussion}

Data collection techniques used data triangulation, including observation, interviews, and documentation can be described as follows: 1) Observation: The study uses participation while observing. Moderate participatory observation is a balanced observation where the researcher is an outsider and an insider, so that when collecting data, the researcher participates in some activities but not all activities. In this study, observations were undertaken while the teacher conducted the learning process in the classroom. 2) Interview: In this study used semi-standard interviews. Semi-standard interviews are one type of in-depth interview category that are conducted more freely than structured interviews. In this interview, the interviewer prepares an outline of the conversation, but during the interview the interviewer asks questions freely, the outline of the main questions does not have to be asked in sequence and the sentences do not have to be rigid but can be modified according to the situation when the interview is held. In this study, interviews were conducted using an interview outline about the strategies that have been tried by the teacher through narration to be able to attract students' involvement and understanding in learning. 3) Documentation: The documentation in this study aims to strengthen data on the development of thematic integrative printed textbooks into the narrative structure of educative comics.

PQ4R learning strategy is regarded as one of the strategies having the potential to empower students' critical thinking skills. Related research results as reported by Wahyuningsih (2012), Bibi and Manzoor (2011). Learning Model of PQ4R (Preview, Question, Read, Reflect, Recite, and Review) The PQ4R learning model is a cooperative learning model developed by Robinson (1972) which was previously known as SQ3R. This model can assist students to remember what they have read or studied. Slavin asserts that through the PQ4R steps, students will focus on organizing meaningful information and involving them in effective activities, such as formulating questions, translating, and recalling the information they receive. Agus, et al. also argue that learning with the PQ4R cooperative model will provide opportunities for students to find concepts in learning through reading activities as well as systematic steps of Preview, Question, Read, Reflect, Recite, and Review. The PQ4R learning model is used to help students remember what they have read through P activities, namely Preview (reading quickly), Q, namely Question (asking questions about reading) and 4R, namely Read, Reflect, recite (answer questions). ), and Review (repeat the whole reading). In line with the statement above, Ramdiah and Corebima point out that they can show the process of schematic in the human brain so that learning is more meaningful" it implies that this is a further description of the schematic in which the human brain can remember new information so that learning will be more meaningful.

In line with the opinion above, Wahyuningsih (2012) asserts that a comprehensive understanding will last relatively longer in our brains, than simply remembering facts. Therefore, this model can help students in understanding reading comprehensively. In accordance with Widiyanthi, et al, they argue that the PQ4R learning model is a learning model in reading activities that can assist students to think critically and utilize students' memories to understand a learning material. Hayes argues that the PQ4R model can be applied in schools for activities that use substantial textual material and can be used with individual students, small groups, and whole classes. In addition, through the PQ4R model students will get experience directly rather than when they are self-taught. Based on the above opinion, it can be concluded that the PQ4R learning model is a learning model that consists of systematic steps 
and aims to assist students in remembering a material through understanding the concepts built by the students themselves.

\section{Learning model syntax of PQ4R}

1) Preview: Students observe reading material quickly. This is undertaken to determine the general organization, topics, and subtopics that are in the outline. 2) Questions: Students ask themselves about the reading material they have presented before reading it. Questions can be created in several ways, who, when, where, why, how. 3) Read: Students read and they are then directed to find answers to the questions that have been made in the previous step. 4) Reflect: Students try to understand what they have read, with things they already know, connect sub-topics in the text with concepts, and relate what they read to the facts at hand. 5) Say: Students are trained to remember learned information and ensure students can repeat what they have read and understand and are able to formulate concepts.

Strengths and Weaknesses of the PQ4R Learning Model. Knowing the strengths and weaknesses of this learning model is very important to support the smooth learning process. The strengths of the PQ4R learning model are: a) it can assist students with low memory to memorize lesson concepts, b) easy to apply at all levels of education, c) able to assist students in improving the skills of the process of asking questions and communicating knowledge, and d) being able to reach subject matter in a wide range. While the weaknesses of the PQ4R learning model are: a) it is very difficult to implement if it facilities such as student books (package books) are not available in schools and b) are not effectively applied in classes with too large a number of students because teacher guidance is not optimal, especially in formulating questions.

To overcome the first shortcoming, the reading material used can be from sources outside the textbook or from the teacher and to overcome the second shortcoming, this learning model can be implemented in groups so that the teacher can control all students, if it is carried out individually, students who already understand can help their friends to formulate questions. The strengths of this learning model are it can overcome the existing shortcomings, the use of this model can be maximized so that it can provide benefits for teachers and students.

\section{Conclusion}

In light of the preliminary research and literature review on the application of the PQ4R learning model to improve students' reading comprehension skills, it can be concluded that the PQ4R learning model can help students improve their reading comprehension skills. Learning by following the steps in the learning model can help students build their own knowledge, comprehend the text more thoroughly, and become more actively involved in the learning process. Teachers can apply the PQ4R learning approach in the classroom, according to the study. The teacher must motivate and always follow the students during the execution of this learning model in order for them to be actively involved in learning activities and for the learning to be more meaningful.

\section{References}

Bibi, R. and Manzoor H. A. (2011). Effect of PQ4R study strategy in scholastic achievement of secondary school student in Punjab (Pakistan). Language in India. 11(12), 247-267.

Depdiknas .2003. Undang-undang RI No.20 Tahun 2003. tentang Sistem Pendidikan Nasional.

Rohani, Ahmad. (1997). Media instruksional edukatif. Jakarta: PT. Rineka Cipta.

Thomas, E. L. \& Robinson, H. A. (1972). Improving reading in every class: Asourcebook for teachers. Boston. http://www.une.edu/cas/lac/learning/pdf/pq4r.pdf (28/05/09).

Wahyuningsih, A. N. (2012). The development of illustrated comics for nervous system learning material for the learning activity implementing PQ4R Strategy. Journal of Innovative Science Education. JISE, 1(1), 19 - 27. 